\section{Microscopy and Microanalysis of Magmatic and Metamorphic Minerals - Part 1: Cordierite}

\author{
Robert Sturm \\ Brunnleitenweg 41, A-5061 Elsbethen, Salzburg/Austria \\ Robert.Sturm@sbg.ac.at
}

\section{Introduction}

Cordierite represents an orthorhombic ( $\mathrm{Mg}, \mathrm{Fe}) \mathrm{Al}$-silicate (Table 1) that is observed in a wide range of natural occurrences. As outlined in numerous mineralogical overviews published during the past decades ${ }^{(1,2)}$, cordierite mainly crystallizes in thermally metamorphosed rocks, particularly in those derived from argillaceous sediments. Additionally, the mineral can be a major constituent of parageneses formed under high-grade regional metamorphism and therefore occurs in respective schists, gneisses and granulites. The metamorphic formation of cordierite is generally restricted to conditions of deficient or low shearing stress producing only moderate lithological pressures. ${ }^{(3)}$ With rising pressure due to transpression cordierite often breaks down to enstatite and sillimanite or, at higher temperature, to sapphirine and quartz (see also Fig. 5). ${ }^{(2,4)}$ Besides its crystallization in metamorphic rocks, cordierite is also found in specific igneous rocks like peraluminous granites and related high-grade anatectic terrains. Here, the mineral is considered as a product of subsolidus metamorphic reactions, a

Cordierite - Chemical composition

$$
(\mathrm{Mg}, \mathrm{Fe})_{2} \mathrm{Al}_{3}\left[\mathrm{AlSi}_{5} \mathrm{O}_{18}\right]
$$

\section{Cordierite - Physical properties}

Crystal habit Pseudo-hexagonal prismatic twins, as embedded grains, massive
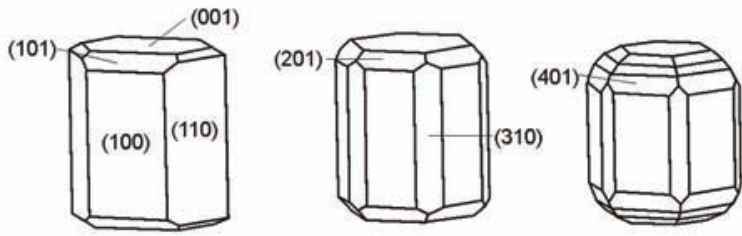

Color

Blue, violet, yellow-brown; transparent to translucent

Crystal system

Orthorhombic $2 / \mathrm{m} 2 / \mathrm{m} 2 / \mathrm{m}$

Cleavage $\quad\{010\}$ poor cleavage

Fracture Conchoidal, uneven

Mohs scale

hardness

$7-7.5$

Refractive

index

Optical

properties

$\alpha=1.522-1.558, \beta=1.524-1.574$

$Y=1.527-1.578$; index increases with Fe content

Pleochroism

Usually optical (-), somtimes (+); $2 \mathrm{~V}=0-90^{\circ}$

Streak

Strong, dichroic: brown-yellow, light and dark blue

Specific gravity

White

Table 1. Overview of the chemical composition and physical properties of cordierite. product of peritectic reactions at the granite source or a utivale of argillaceous material contaminating the granitic magma. ${ }^{(1,5)}$ Among some authors cordierite is also considered as a cotectic magmatic mineral or a mineral phase formed by metasomatism which directly followed the process of granitization. ${ }^{(6,7)}$ Cordierite of gem quality often occurs in granite pegmatites, where it usually crystallizes from uncontaminated pegmatitic liquids. A previous crystallization from residual magmas enriched with Al-silicates is also discussed. Concerning its physical properties being essential for macroscopic and light-microscopic identification, cordierite exhibits some similarities to other minerals, especially to quartz and feldspar (Table 1). In the contribution presented here, cordierite and its specific microscopic/microchemical characteristics are introduced to microscopists with enhanced mineralogical interest. The detailed description of the mineral is conducted using respective samples from an ultramylonite (i.e. a fine-grained rock formed by a ductile shearing process) exposed at the South-western margin of the Bohemian Massif in Austria (Fig. 1,2).

\section{Material and methods}

One part of the samples taken from the ultramylonite was used for the production of oriented thin sections, serving for lightmicroscopy. This was conducted on a petrographic microscope (ZEISS), appropriately equipped for dark-field microscopy. In addition, polished thin sections for micro-chemical analysis and

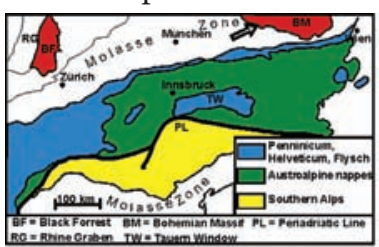

NNW

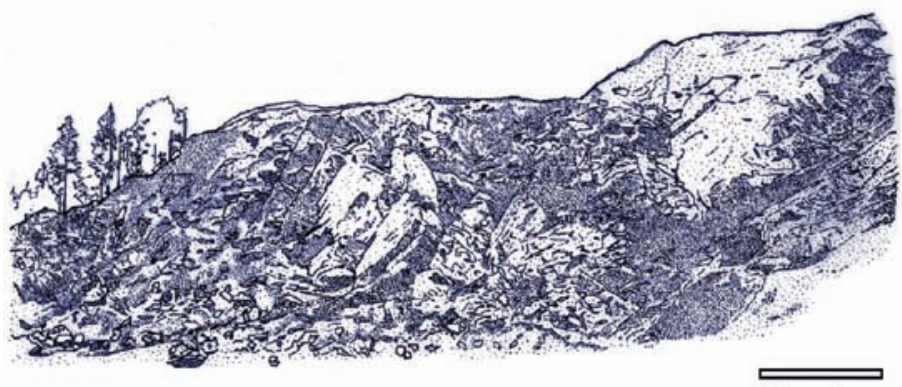

10 metres
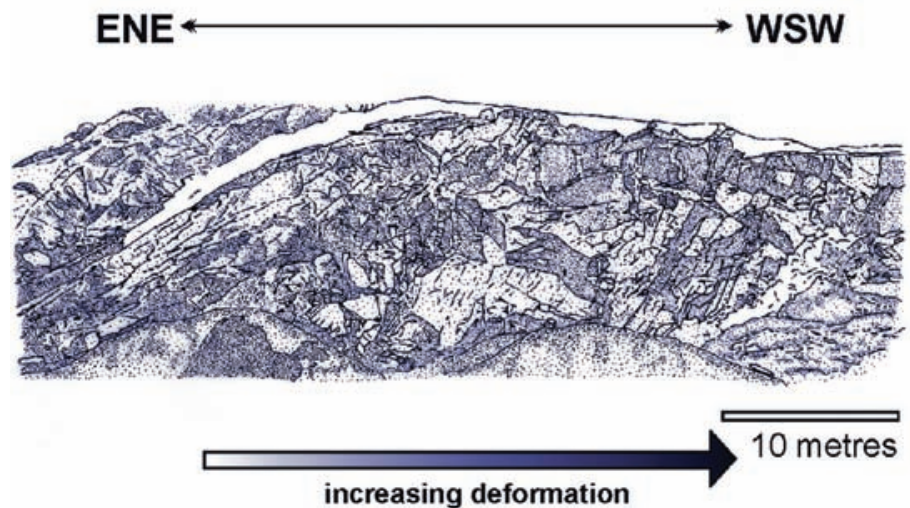

\section{increasing deformation}

Fig. 1. Upper left: Geological map showing the major tectonic units in Central Europe and the geographic position of the rocks analyzed in this study; draft exhibiting the quarry, from which cordierite-bearing rocks were sampled. 
What have we achieved in this period?

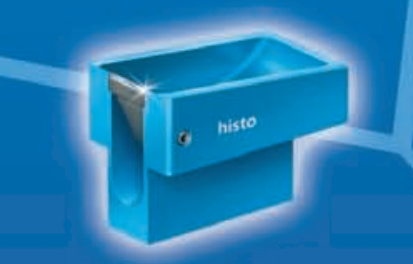

\section{ultra $45^{\circ}$}

the first diamond knife with an absolutely

score-free, hydrophilic cutting edge.

\section{semi}

the first diamond knife for alternating

sectioning ultrathin/semithin.

cryo.

the diamond knife for sectioning at low temperature.

histo

the first diamond knife for semithin sections for light microscopy.
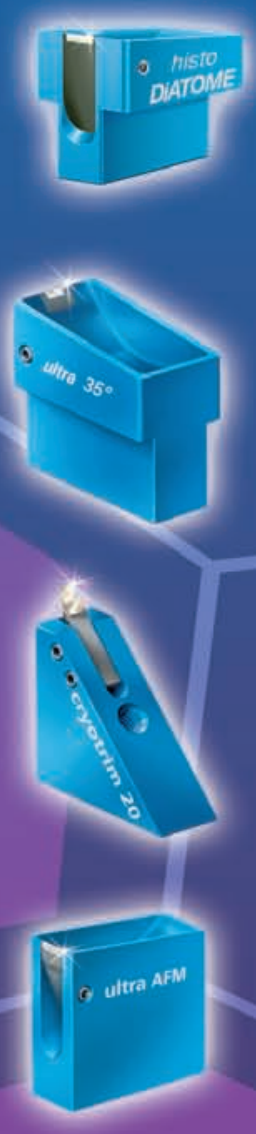

\section{DHATONE}

for all your sectioning requirements

\section{ultra $35^{\circ}$}

the diamond knife for optimized sectioning results in almost all applications.

cryo-P

a cryo knife with a patented platform for section pick up.

cryo immuno

the optimized cryo diamond knife for the Tokuyasu technique.

ultra sonic the oscillating diamond knife for room temperature sectioning

\section{cryotrim}

45 and 25 optimizing trimming with diamond blades.

\section{ultra AFM \& cryo AFM} the first diamond knives for AFM at room and low temperatures.

cryo $25^{\circ}$

for sectioning frozen hydrated specimens.

\section{STATIC LINE II}

the ionizer for eliminating electrostatic charging in ultramicrotomy.

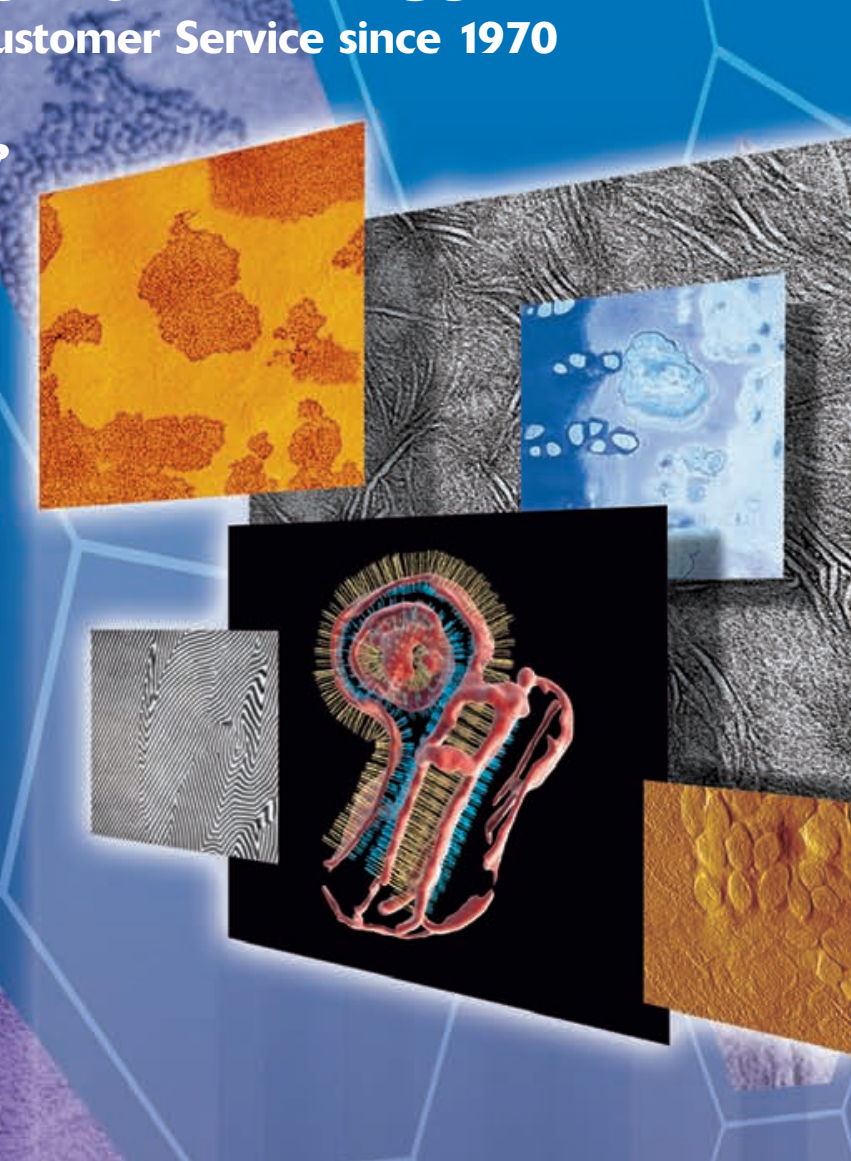

What services can we offer you?

Technical assistance in all fields of ultramicrotomy.

Free sectioning tests for all types of samples.

Make use of our many years of experience in perfecting our knives.

Custom knives, tools, and boats.

Special purchase programs.

Workshops and training.

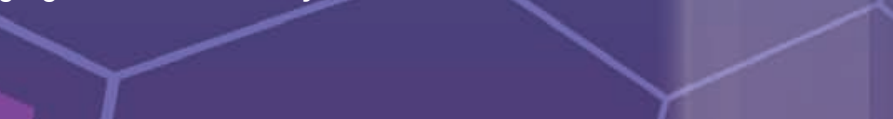

\section{For more information, please call or write us today, or visit us online at:}

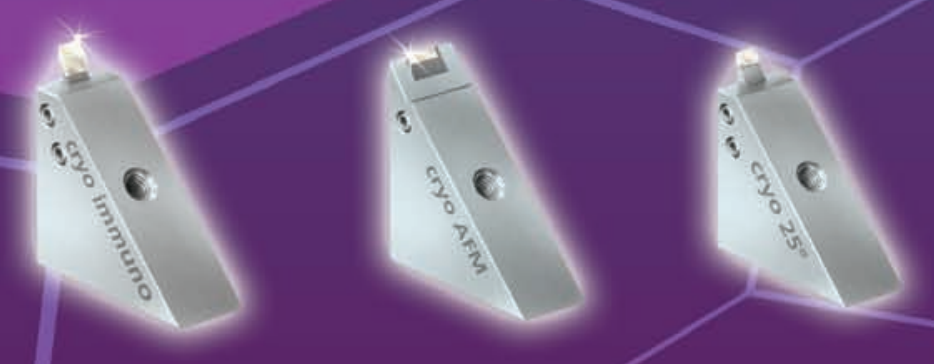

www.diatomeknives.com

P.O. Box $410 \bullet 1560$ Industry Rd. Hatfield, Pa 19440

(215) 412-8390 • Toll Free: 1-(800) 523-5874

Fax: (215) 412-8450 or 8452

email: sgkcck@aol.com•stacie@ems-secure.com 


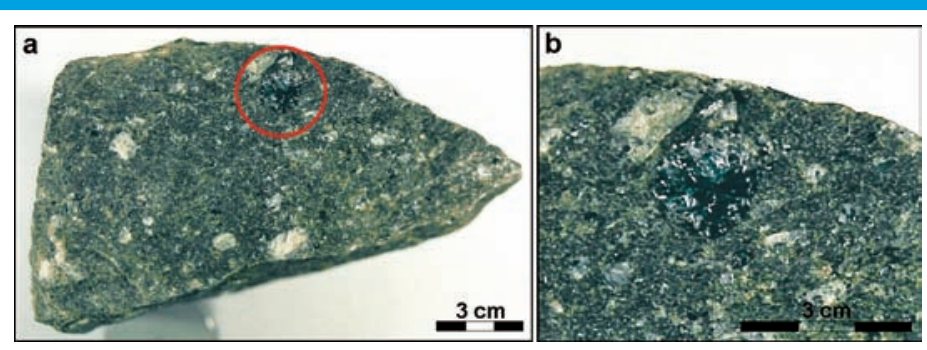

Fig. 2. Sample of the cordierite-bearing ultramylonite (a) containing a blue cordierite crystal characterized by remarkable size (b).

back-scattered electron imaging (BSEI) were produced. These procedures were carried out on a JEOL JXA-8600 microprobe at the institute of Geology, University of Salzburg. Operating parameters were set as follows: $30 \mathrm{nA}$ beam current, $15 \mathrm{kV}$ accelerating voltage, $10 \mathrm{~s}$ counting time for each element except $\mathrm{Ti}$ and $\mathrm{Na}$ (30 s), and a constant beam diameter of $1 \mu \mathrm{m}$. Natural and synthetic silicates and oxides served as standards for the main element analysis. ${ }^{(8)}$ Correction of the raw analyses was done by the application of an internal ZAF-4 procedure. The element analyses produced experience an average error not exceeding $0.1 \mathrm{wt} . \%$. For $\mathrm{Na}_{2} \mathrm{O}$ the detection limit is $0.050 \mathrm{wt} . \%$ employing operating parameters as detailed above. Back-scattered electron imaging of unaffected as well as partly and fully decomposed cordierites was carried out by turning up the beam current from $30 \mathrm{nA}$ to $40 \mathrm{nA}$ in order to increase the contrast for photography.

\section{Cordierite from the Bohemian Massif}

The ultramylonite as well as its surrounding lithology can be assigned to the Southwestern margin of the Bohemian Massif (Fig. 1). This Variscan massif is mainly located within the CentralEuropean Moldanubian zone ${ }^{(9)}$, characterized by widespread high-temperature/low-pressure metamorphism, partial melting processes and extensive plutonism. The geology of the study area is marked by Variscan migmatites and gneisses of the so-called Monotonous series that have been intruded by post-Variscan granite bodies. During the Tertiary, NW-SE tending strike-slip faults (Pfahl and Danube fault) with variable shear sense were formed and divided the lithology into three main granitic bodies. (10) The rock of the present study was produced in a local dextral shear zone that can be interpreted as a side branch of the Pfahl fault. The quarry, in which the cordierite-bearing ultramylonite is found (Fig. 1: arrow in the map) consists of two orthogonal walls, whereby on the WSW-ENE-tending wall metamorphic rocks with
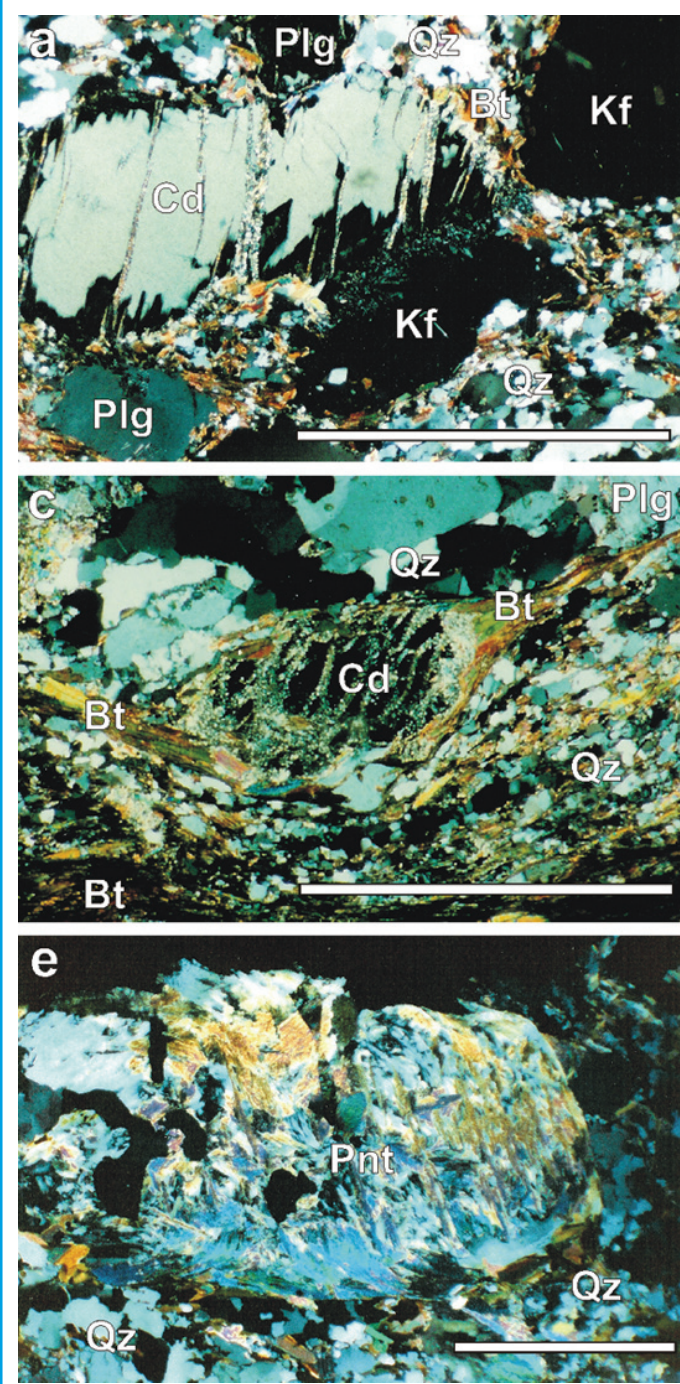

Fig. 3. Microphotographs of the mineral assemblage, which the ultramylonite is mainly composed of. Unaffected cordierite (Cd) may be identified due to its typical cracks and dark corona (a). During uplift of the rock, cordierite is marked by a continuous decomposition, finally resulting in pinite (Pnt; $b-f)$. Further abbreviations: Bt...biotite, Kf...K-feldspar, Mu...muscovite, Plg...plagioclase, Qz...quartz. Bars represent $1 \mathrm{~mm}$, respectively.
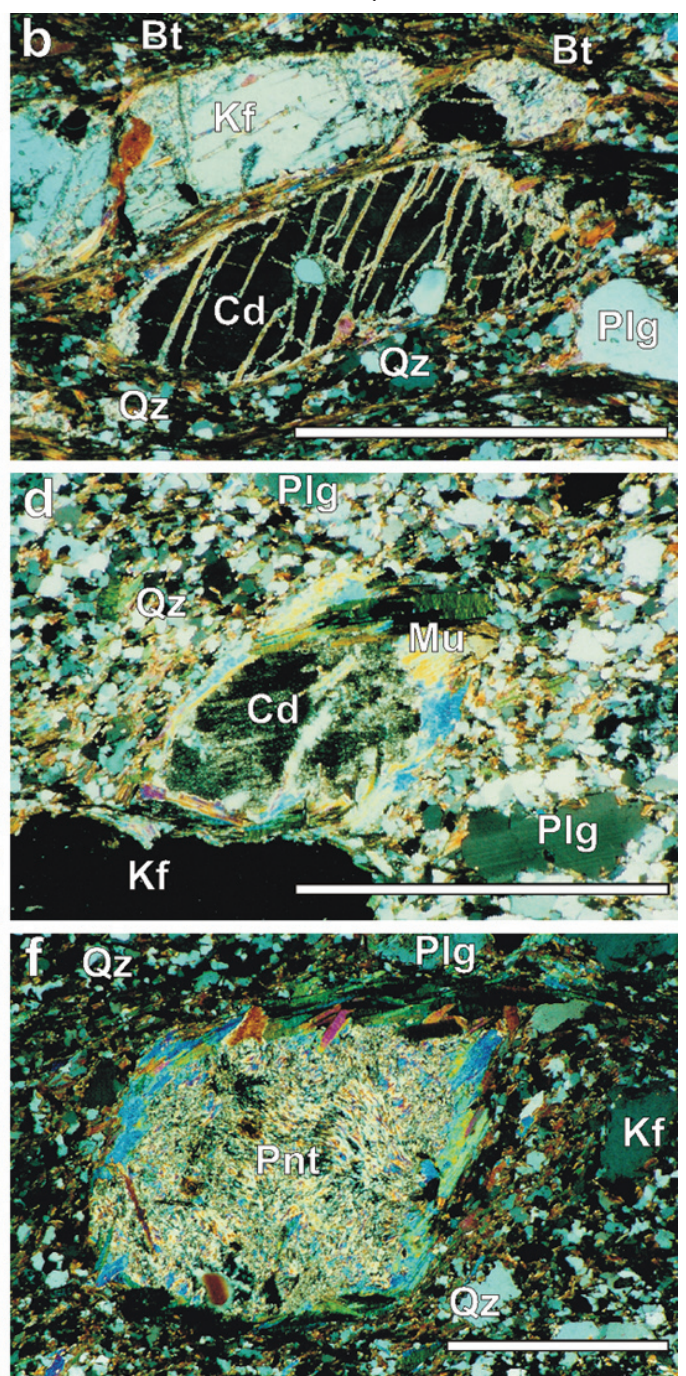

Kf.

(c). are recrystallized in high amounts (Fig. 3) and can be accumulated to specific aggregates or layers. Biotite is often accompanied by fibrolitic sillimanite and muscovite. The porphyroclasts and -blasts of the rock are mainly represented by feldspar 


\section{from experience... learn from the experts.}

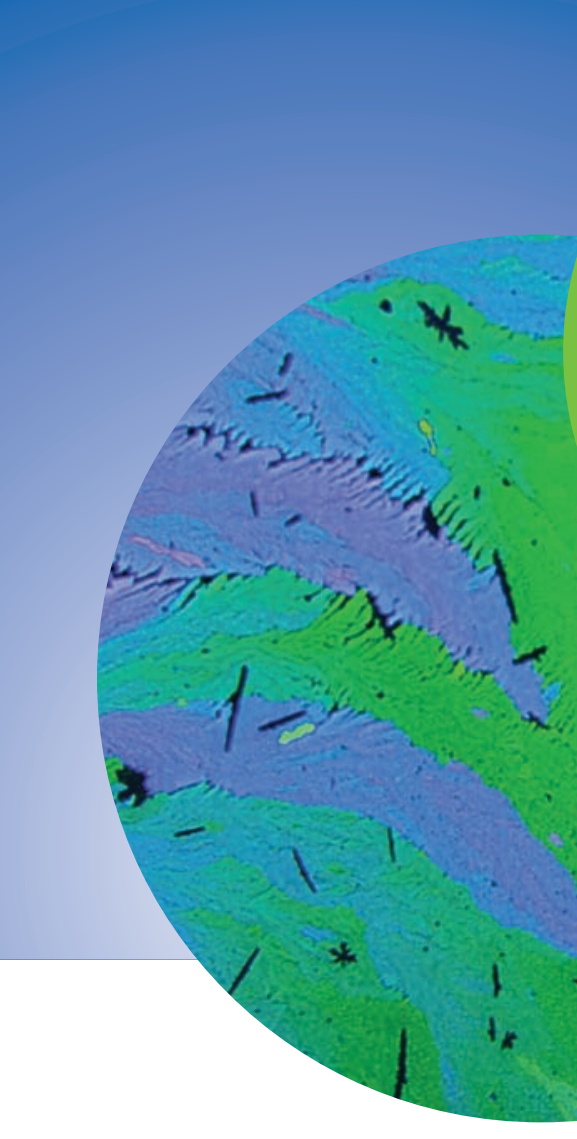

Polarized Light Microscopy COM100

Modern Polarized Light \& Chemical Microscopy May 4-8, 2009

\section{Electron Microscopy \\ COM200}

Scanning Electron Microscopy

March 16-20, 2009

\section{COM210}

Advanced Scanning Electron Microscope

Based Tools for Microanalysis

February 9-13, 2009

\section{COM250}

Transmission Electron Microscopy

March 24-26, 2009

\section{Sample Preparation \\ COM310}

Sample Preparation:

Pharmaceutical \& Medical Devices

May 18-19, 2009

\section{COM312}

Sample Preparation: Forensics \& Trace Evidence June 11-12, 2009
Biological/Medical COM700

Body Fluid Identification \& Microscopical Methods of Sperm Detection for Forensic DNA/Serology/Biology April 28-30, 2009

Cultural Preservation and Conservation Studies C0M801

Laboratory Safety

June 5, 2009

COM870

Spot Testing for Materials

Characterization

May 4-8, 2009

\section{Special Applications}

COM400

Microscopical Examination of Forensic Trace Evidence (Part 1)

June 15-19, 2009

\section{COM401}

Hair Comparisons \& Identification

April 20-24, 2009

\section{COM402}

Fiber Identification

April 13-17, 2009

\section{COM410}

Microscopical Identification of Pharmaceutical Materials

\& Contaminants

May 11-15, 2009

COM415

USP $\{788\}$ Particulate Matter

in Injections

May 21, 2009

\section{COM425}

Introduction to the Microscopical Identification of Conservation

Materials

June 8-12, 2009

\section{COM430}

Microscopical Identification of White-Powder Unknowns February 23-27, 2009

\section{COM450}

Freeze-Dry Microscopy

May 5-7, 2009
2009 COURSE SCHEDULE Winter/Spring 


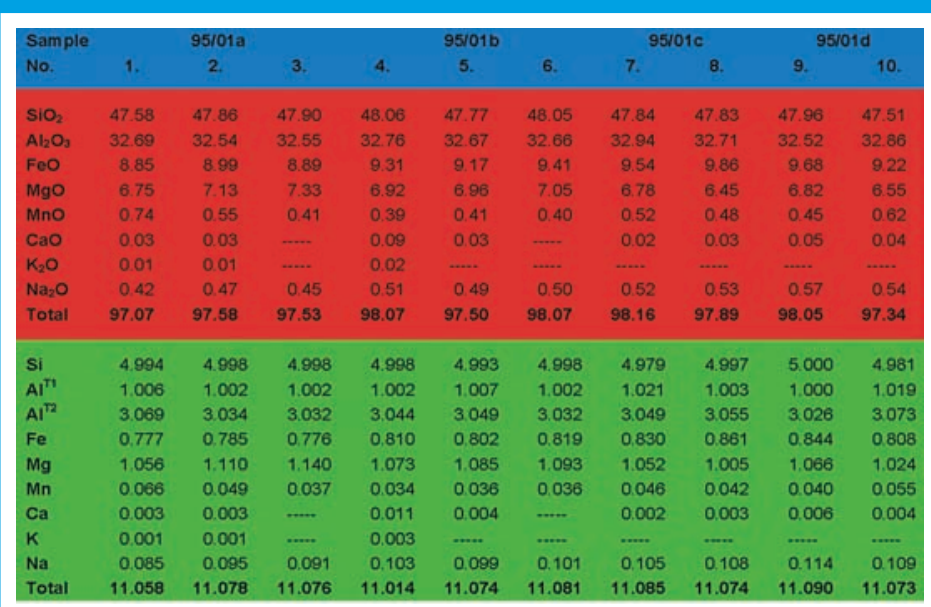

Table 2. Chemical composition of cordierite from the ultramylonite discussed in this study. All together, four rock samples were subject to a micro-chemical analysis using the electron microprobe.
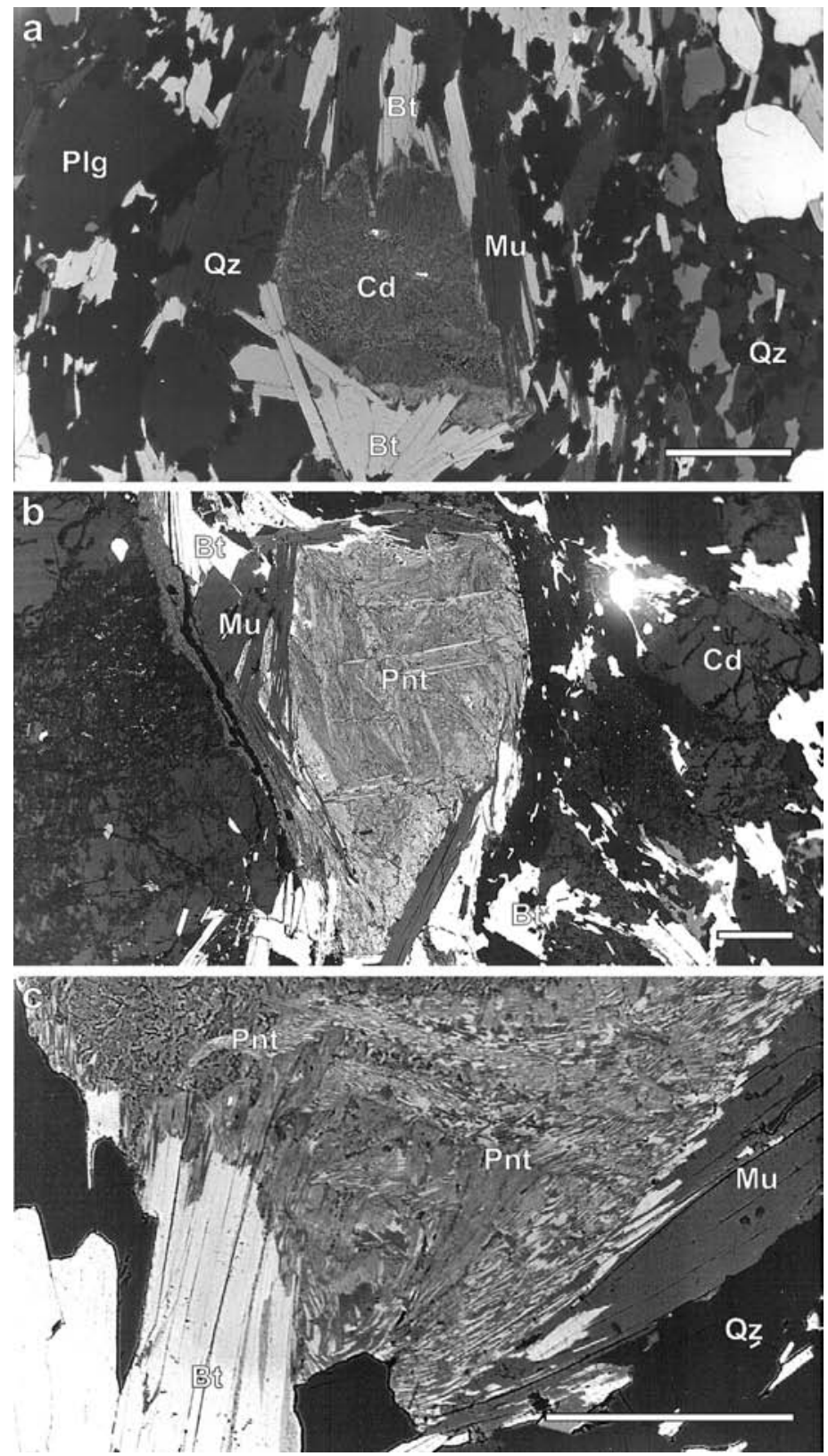

Fig. 4. Back-scattered electron images of nearly unaffected ( $a-b)$ and pinitized cordierites (b-c). For abbreviations see Fig. 3. Bars represent 100 $\mu m$, respectively. relics and cordierite and partly show a significant rotation parallel to the deformation plane (e.g. Fig. 3b).

Under the light-microscope, cordierite crystals appear as isometric to slightly elongated grains surrounded by a fine matrix of quartz, biotite, mica, and sillimanite. Those grains not affected by pinitization (see below), are easily identifiable due to dark cracks and coronas (e.g. Fig. 3a) as well as their typical pleochroism. While ca. $30 \%$ of the grains are free from inclusion phases, the remaining $70 \%$ contain quartz, relictic biotite, sillimanite, and garnet.

Microprobe analyses of cordierite crystals underline that the mineral is characterized by a rather homogeneous chemistry (Table 2). In contrast to the ideal structural formula of cordierite (Table 1), a slight deficiency in $\mathrm{Si}$ (< 5.0 p.f.u.) and excess in $\mathrm{Al}(>$ 4.0 p.f.u.) can be recognized. The sum of both tetrahedral cations varies between 9.030 and 9.080 and therefore deviates from the ideal value of 9.00 by 0.33 to $0.88 \%$. The replacement of octahedral $\mathrm{Mg}$ by $\mathrm{Fe}^{2+}$ and $\mathrm{Mn}$ is documented by a $\mathrm{Mg} /\left(\mathrm{Mg}+\mathrm{Fe}^{2+}+\mathrm{Mn}\right)$ ratio ranging from 0.543 to 0.584 . These values confirm a predominance of $\mathrm{Mg}$ in the octahedral sites. $\mathrm{MnO}$ plays a minor role in the major-element composition, reaching a maximum value of

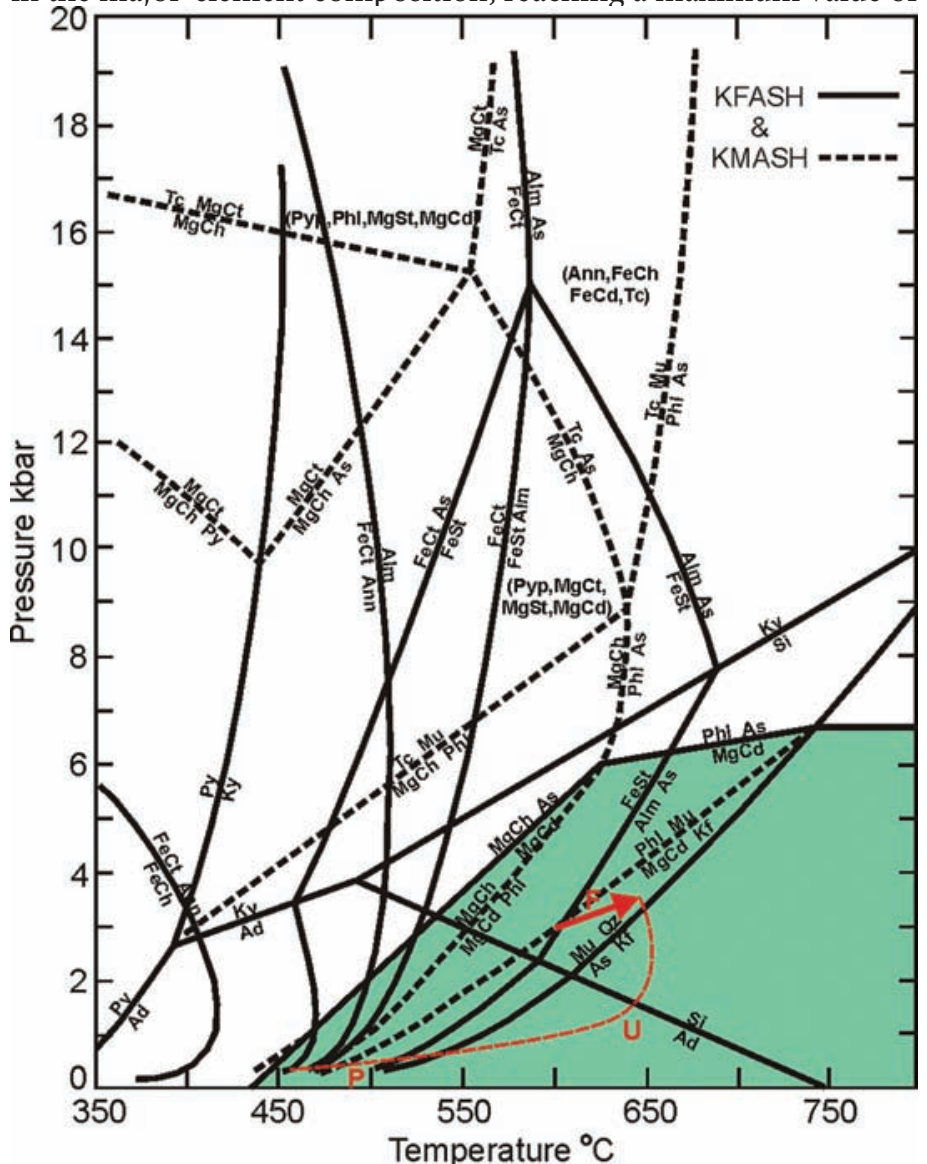

Fig. 5. $P$-T diagram with essential mineral reactions of the KFASH $\left(\mathrm{K}_{2} \mathrm{O}-\mathrm{FeO}-\mathrm{Al}_{2} \mathrm{O}_{3}-\mathrm{SiO}_{2}-\mathrm{H}_{2} \mathrm{O}\right)$ and the KMASH $\left(\mathrm{K}_{2} \mathrm{O}-\mathrm{MgO}-\mathrm{Al}_{2} \mathrm{O}_{3}-\mathrm{SiO}_{2}\right.$ $\left.\mathrm{H}_{2} \mathrm{O}\right)$ system $^{(2)}$ as well as the approximate stability field of cordierite (green). The arrow indicates temperature and pressure during formation $(F)$ of the ultramylonite, while the dashed curve represents respective $P-T$ conditions during rock uplift $(U)$ and pinitization $(P)$. Abbreviations: Ad...andalusite, Alm...almandine, Ann...annite, As...alumosilicate, $\mathrm{FeCd}$...Fe-cordierite, $\mathrm{FeCh}$...Fe-chlorite, $\mathrm{FeCt}$...Fe-chloritoid, FeSt... $\mathrm{Fe}$-staurolite, $\mathrm{Kf} \ldots \mathrm{K}$-feldspar, $\mathrm{Ky} \ldots$...kyanite, $\mathrm{MgCd} \ldots \mathrm{Mg}$-cordierite, $\mathrm{MgCh} . . . M g$-chlorite, $\mathrm{MgCt}$...Mg-cloritoid, MgSt...Mg-staurolite, $\mathrm{Mu}$.. muscovite, Phl...phlogopite, Py...pyrophyllite, Pyp...pyrope, Qz...quartz, Si...sillimanite, Tc...talc. 


\section{Side-By-Side Comparison? Difficult When Our Coaters Stand Alone.}

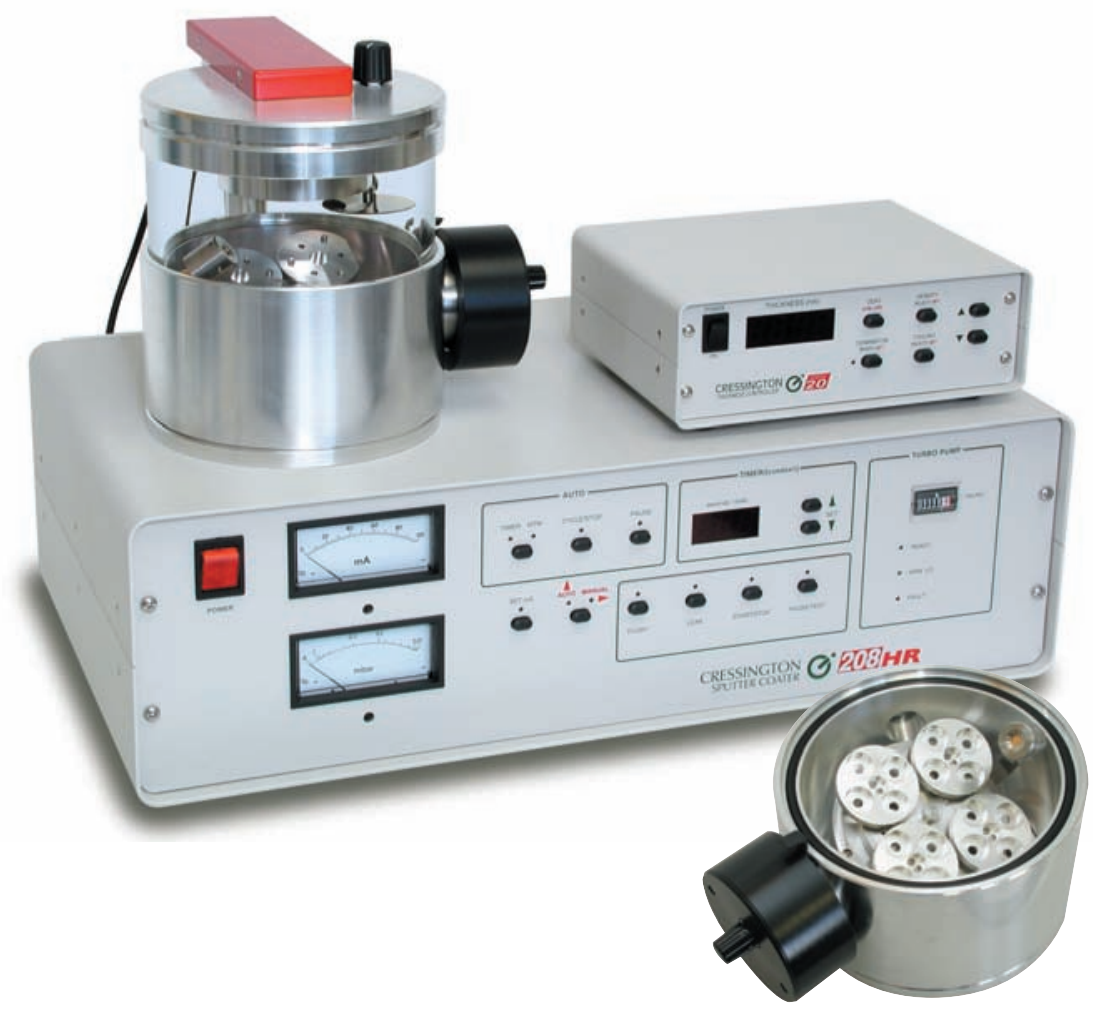

High Resolution Sputter Coater 208HR for FE-SEM

\section{Superior Features:}

- High Resolution Fine Coating

- Wide Choice of Coating Materials

- High Resolution Thickness Control

- Multiple Sample Stage Movements

- Wide Range of Operating Pressures

- Compact, Modern, Benchtop Design
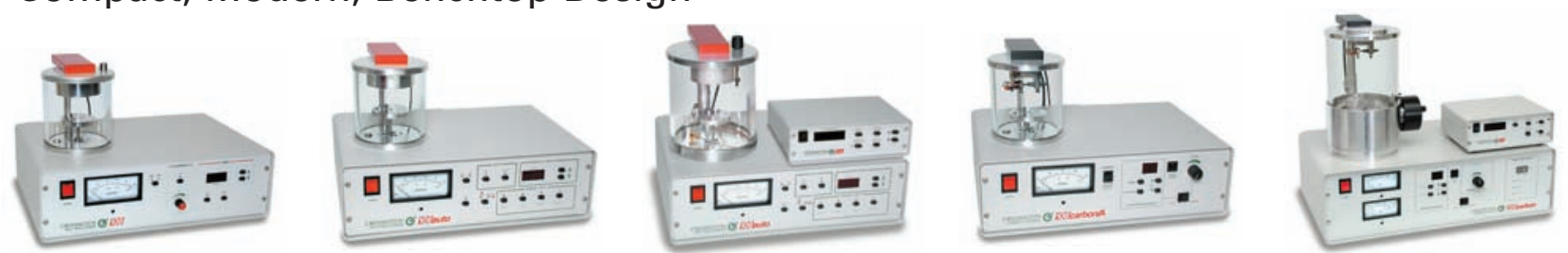

Find out about our complete line of sample coaters.

$\checkmark \triangle T E D$ PELLA, INC.

Microscopy Products for Science and Industry
4595 Mountain Lakes Blvd., Redding, CA 96003-1448

Phone: 530-243-2200 or 800-237-3526 (USA) FAX: 530-243-3761

Email: sales@tedpella.com Web Site: www.tedpella.com 
0.74 wt.\% (Table 2). The sum of all octahedral cations ranges from 1.900 to 1.965 , deviating from the ideal formula by 2 to $5 \%$. CaO and $\mathrm{K}_{2} \mathrm{O}$ can be detected sometimes in very low amounts $(0.002$ to $0.009 \mathrm{wt} . \%$ and 0.001 to $0.002 \mathrm{wt} . \%$, respectively), and therefore seem to be of negligible importance concerning the occupation of the crystal channels. In contrast, $\mathrm{Na}_{2} \mathrm{O}$ is present in the channels with a concentration varying between 0.42 and $0.57 \mathrm{wt} . \%$. The formulae listed in Table 2 yield evidence that the insertion of $\mathrm{Na}$ and $\mathrm{K}$ into the channels is mainly caused by a coupled substitution of $(\mathrm{Na}, \mathrm{K})+\mathrm{Al}$ against the $+\mathrm{Si}$ channel site. The sum of all analyzed oxides ranges from $97.07 \mathrm{wt} . \%$ to $98.16 \mathrm{wt} . \%$ suggesting the introduction of about 2-3 wt.\% of volatile compounds $\left(\mathrm{H}_{2} \mathrm{O}\right.$, $\mathrm{CO}_{2}$ ) into the crystal lattice (Table 2).

As could be established by several analyses on a single grain, cordierite from the ultramylonite does not show significant compositional zoning due to a possible variation of the $\mathrm{Mg} /\left(\mathrm{Mg}+\mathrm{Fe}^{2+}\right.$ $+\mathrm{Mn})$ ratio from the crystal core to its rim. The ratio fluctuates between 0.561 and 0.566 (Table 2, analyses 5 and 6), but does not follow any remarkable trend. It must be noted that many cordierites of this micro-chemical investigation are characterized by a marginal replacement by pinite, which could be a reason for the destruction of a former compositional zoning.

\section{Formation and decomposition (pinitization) of cordierite}

Temperatures of mylonitization and cordierite formation were estimated using the $\mathrm{Na}$-in-cordierite thermometer ${ }^{(11)}$ and the garnet-cordierite $\mathrm{Fe} / \mathrm{Mg}$-exchange thermometer. ${ }^{(12)}$ Temperatures calculated on the basis of the Na contents range from 586 to $630^{\circ} \mathrm{C}$, exhibiting a significant decrease from the centre to the edge of the shear zone (Fig. 5). Garnet-cordierite temperatures, on the other hand, range from 593 to $639^{\circ} \mathrm{C}$ within a presumed pressure interval of $0.30-0.40 \mathrm{GPa}$, thereby showing a similar decrease along the shear zone profile as the temperatures derived from the Na-incordierite thermometer. Estimation of related pressures is mainly based on assumptions concerning the formation of cordierite and related mineral reactions, the stability of cordierite and its dependence on the $\mathrm{Mg} /(\mathrm{Mg}+\mathrm{Fe})$ ratio, and the stability of other mineral constituents. A very coarse evaluation of pressure during metamorphism is possible by the fact that fibrolitic sillimanite is the only $\mathrm{AlSiO}_{5}$ phase occurring in the studied mylonites. Considering a temperature range of $570-620^{\circ} \mathrm{C}$ and the stability field of sillimanite within the system kyanite-andalusite-sillimanite, pressure had to be higher than ca $0.35 \mathrm{GPa}$ (Fig. 5).

The ultramylonite offers a possibility for studying various stages of cordierite decomposition during uplift of the host rock (Fig. 5). This so-called pinitization, which may be expressed by the chemical reaction

$$
\text { cordierite }+ \text { biotite }+\mathrm{H}_{2} \mathrm{O} \rightarrow \text { muscovite }+ \text { chlorite }+ \text { quartz }
$$

and starts at temperatures of $475-500{ }^{\circ} \mathrm{C}^{(2)}$, ranges from only poorly affected grains to fully transformed grains (Fig. 3a-f). In the first stage, cracks running through the mineral are continuously filled with very fine crystals of mica and chlorite (Fig. 3b-c). Subsequently, the margins of cordierite are transformed into muscovite, chlorite and biotite of variable size (Fig. 3c). In a medium stage of decomposition, internal pinitization undergoes a significant progression, forming aggregates of mainly mica, biotite, and chlorite (Fig. 3d). In the last stage of pinitization, the former cordierite has been fully transformed into bluish-green pinite which is demarcated from the matrix by a mantle of muscovite and biotite crystals. If the decomposition process is accomplished by local shear strain, the resulting pinitic blast is marked by a sigmoidal shape and internal microcrenulation (Fig. 3e-f).

When studied with the electron microprobe in back-scattered electron mode, pinites show a fine discontinuous corona of replacing minerals, which itself is surrounded by large grains of biotite and muscovite (Fig. 4). This outer corona demarcates the blast from the surrounding matrix, adjacent feldspar clasts, and relics of quartz.

\section{Conclusion}

As demonstrated by the study presented here, cordierite represents a metamorphic mineral phase of interest for the geoscientist but also for the microscopist. In petrographic thin-sections, the mineral is characterized by a typical appearance (see Fig. 3) and therefore can be easily distinguished from adjacent mineral phases with similar optical properties (e.g. quartz, untwinned feldspar). In micro-chemical respects, cordierite contains a significant amount of volatile phases $\left(\mathrm{H}_{2} \mathrm{O}, \mathrm{CO}_{2}\right)$ which may affect specific physical characteristics (e.g. colour, specific gravity, refraction index, etc.) to a certain degree. As exhibited by cordierite-rocks sampled from the South-western margin of the Bohemian Massif in Austria, cordierite is commonly formed during medium- to high-grade metamorphic deformation marked by temperatures $>500^{\circ} \mathrm{C}$ and lithological pressures $<0.6 \mathrm{GPa}$. During uplift and cooling of the lithological unit, within which cordierite was formed, the mineral phase is often subject to a typical decomposition process (see formula 1) that is widely known as pinitization. This process may also be of enhanced interest for microscopists, because within one rock sample, several stages of pinitization may be observed at the same time. Since factors controlling cordierite formation and decomposition are not fully decoded yet, the mineral will still be an object of increased geoscientific interest in future.

\section{References}

(1) Deer W. A., Howie, R. A. \& Zussman J. (1992): An Introduction to the RockForming Minerals. 2nd ed., Longmans Scientific and Technical, London.

(2) Spear, F. S. (1993): Metamorphic Phase Equilibria and Pressure-TemperatureTime Paths. Mineralogical Society of America (MSA), Washington D.C.

(3) Harker, A. (1939): Metamorphism. 2nd ed., Methuen \& Co, London.

(4) Seifert, F. (1970): Low-temperature Compatibility Relations of Cordierite in Haplopelites of the System $\mathrm{K} 2 \mathrm{O}-\mathrm{MgO}-\mathrm{Al} 2 \mathrm{O} 3-\mathrm{SiO} 2-\mathrm{H} 2 \mathrm{O}$. Journal of Petrology 11, 73-100.

(5) Wall V. J., Clemens J. D. \& Clarke, D. B. (1987): Models for granitoid evolution and source compositions. Journal of Geology 95, 731-750.

(6) Clarke, D. B. (1981): The mineralogy of peraluminous granites; a review. Canadian Mineralogist 19, 3-17.

(7) Clemens, J. D. \& Wall, V. J. (1981): Origin and crystallization of some peraluminous (S-type) granitic magmas. Canadian Mineralogist 19, 111-131.

(8) Sturm, R. (2008): Microscopy and Microanalysis of Corona Textures in Eclogitic Greenschists from the Eastern Alps, Austria. Microscopy Today 16/2, 26-31.

(9) Kossmat, F. (1927): Gliederung des varistischen Gebirgsbaus. Abhandlungen der Sächsischen Geologischen Landesanstalt 1, 1-39.

(10) Frasl G. \& Finger F. (1991): Geologisch-petrographische Exkursion in den österreichischen Teil des südböhmischen Batholiths. Beihefte zum European Journal of Mineralalogy 3, 23-40.

(11) Mirwald, P. W. (1986): Ist Cordierite in Geothermometer? Fortschritte der Mineralogie 64, 119.

(12) Perchuk, L. L. \& Lavrent'eva, I. V. (1981): Experimental investigation of exchange equilibria in the system cordierite-garnet-biotite. In: Saxena, S. K. (ed.): Kinetics and Equilibrium in Mineral Reactions, Springer, New York, 199-240. 
